\title{
Microbes Associated with Freshly Prepared Juices of Citrus and Carrots
}

\author{
Kamal Rai Aneja, ${ }^{1}$ Romika Dhiman, ${ }^{2}$ Neeraj Kumar Aggarwal, \\ Vikas Kumar, ${ }^{2}$ and Manpreeet Kaur ${ }^{2}$ \\ ${ }^{1}$ Vaidyanath Research, Training and Diagnostic Centre, Kurukshetra 136118, India \\ ${ }^{2}$ Department of Microbiology, Kurukshetra University, Kurukshetra 136119, India
}

Correspondence should be addressed to Romika Dhiman; romikadhiman@gmail.com

Received 24 June 2014; Revised 22 September 2014; Accepted 6 October 2014; Published 19 October 2014

Academic Editor: Rosana G. Moreira

Copyright (C) 2014 Kamal Rai Aneja et al. This is an open access article distributed under the Creative Commons Attribution License, which permits unrestricted use, distribution, and reproduction in any medium, provided the original work is properly cited.

Fruit juices are popular drinks as they contain antioxidants, vitamins, and minerals that are essential for human being and play important role in the prevention of heart diseases, cancer, and diabetes. They contain essential nutrients which support the growth of acid tolerant bacteria, yeasts, and moulds. In the present study, we have conducted a microbiological examination of freshly prepared juices (sweet lime, orange, and carrot) by serial dilution agar plate technique. A total of 30 juice samples were examined for their microbiological quality. Twenty-five microbial species including 9 bacterial isolates, 5 yeast isolates, and 11 mould isolates were isolated from juices. Yeasts and moulds were the main cause of spoilage of juices. Aspergillus flavus and Rhodotorula mucilaginosa were observed in the maximum number of juice samples. Among bacteria Bacillus cereus and Serratia were dominant. Escherichia coli and Staphylococcus aureus were detected in few samples. Candida sp., Curvularia, Colletotrichum, and Acetobacter were observed only in citrus juice samples. Alternaria, Aspergillus terreus, A. niger, Cladosporium, and Fusarium were also observed in tested juice samples. Some of the microorganisms detected in these juice samples can cause disease in human beings, so there is need for some guidelines that can improve the quality of fruit juices.

\section{Introduction}

Unpasteurized fruit juice is defined as the product produced by pressing or squeezing of the fruits [1]. Consumption of fresh juices increased dramatically due to their freshness, high vitamin content, and low caloric consumption [2]. Extracted juices from fruits contain most substances which are found in the original ripe and sound fruit from which the juice is made. The high potassium and low sodium characteristic of most juices help in maintaining a healthy blood pressure. Vitamin C is naturally present in juices which are essential for the body to form collagen, cartilage, muscle, and blood vessels. It also helps in the absorption of iron [3].

Fruit juices contain a microflora which is normally present on the surface of fruits during harvest and postharvest processing which include transport, storage, and processing [4]. Many microorganisms such as acid tolerant bacteria and fungi (moulds, yeasts) use them as a substrate for their growth. Yeasts form the main flora of fruits before processing because of acidic $\mathrm{pH}$. The major genera include Candida, Dekkera, Hanseniaspora, Pichia, Saccharomyces, and Zygosaccharomyces. Penicillium, Byssochlamys, Aspergillus, Paecilomyces, Mucor, Cladosporium, Fusarium, Botrytis, Talaromyces, and Neosartorya are filamentous fungi most frequently isolated from fresh fruits and juices. Among bacteria, lactic acid bacteria and acetic acid bacteria have been isolated from fruit juices [5].

The critical factors affecting the spoilage of juices include juice $\mathrm{pH}$, oxidation reduction potential, water activity, availability of nutrients, presence of antimicrobial compounds, and competing microflora. Among these factors, $\mathrm{pH}$ and water activity are the most influential factors affecting the spoilage of juices. The spoilage caused by microorganisms in juices includes cloud loss, development of off-flavours, $\mathrm{CO}_{2}$ production, and changes in colour, texture, and appearance resulting in degradation of product $[6,7]$. The most 
commonly reported bacterial genera include Acetobacter, Alicyclobacillus, Bacillus, Gluconobacter, Lactobacillus, Leuconostoc, Zymomonas, and Zymobacter. Among yeasts Pichia, Candida, Saccharomyces, and Rhodotorula are commonly encountered genera responsible for spoilage of juices [8]. Certain common moulds such as Penicillium sp., Aspergillus sp., Eurotium, Alternaria, Cladosporium, Paecilomyces, and Botrytis have also been reported in spoilage of fruit juices $[5,6]$.

Fruit juices have $\mathrm{pH}$ in the acidic range $(<4.5)$ serving as important barrier for microbial growth. However, food borne pathogens such as E. coli and Salmonella survive in acidic environment of fruit juices due to acid stress response. Therefore, in the last two decades a number of food borne outbreaks associated with unpasteurized fruit juices have been documented in many countries $[1,9]$. The source of entry of microorganisms into fresh fruit juices from environment exposure and soil. In developing country like India, a large population of all income and age groups consume freshly squeezed fruit and vegetable juice [10], but the presence of pathogenic microorganisms in street vended fruit juices has also been reported in various parts of India such as Vishakhapatnam [11], Mumbai [12], Amravati [13], and Nagpur [10]. In view of the demand for fresh fruit juices throughout the year and threat of emerging food borne outbreaks associated with consumption of fruit juices, the aim of present study was to investigate the microbiological examination of freshly prepared juices commonly consumed in Kurukshetra.

\section{Materials and Methods}

2.1. Fruit Juice Preparation. Three juices commonly consumed in Kurukshetra such as orange (Citrus reticulata Blanco), sweet orange (Citrus sinensis), and carrot (Daucus carota) were selected for microbiological study. Sweet orange, carrot, and orange were purchased from the local markets of Kurukshetra from October 2011 to February 2012. Each sample was washed, peeled, and cut into pieces and juice was extracted through sterile hand blender and poured into sterile beaker.

2.2. Measurement of $p H$. The $\mathrm{pH}$ of juice samples was measured using a $\mathrm{pH}$ meter.

2.3. Microbiological Analysis. The microbiological study of fruit juices was done by serial dilution agar plate technique. Ten $\mathrm{mL}$ of juice sample was diluted with $90 \mathrm{~mL}$ of $0.1 \%$ sterile peptone water (1 $\mathrm{g}$ peptone, $1 \mathrm{~L}$ distilled water) and plated on nutrient agar $(\mathrm{pH}$ 5.5) for enumeration of bacteria and PDA supplemented with antibiotic ( $\mathrm{pH}$ 5.5) for enumeration of fungi in duplicates [4]. Uninoculated plates of PDA and NA were used as control. Mould and yeast isolates were purified on potato dextrose agar, bacteria on nutrient agar, and further subcultured for microscopic examination and identification.

2.4. Identification of Bacteria. For bacterial identification, 24hour-old culture of bacteria was observed under microscope by gram stain method and further various biochemical tests
TABLE 1: $\mathrm{pH}$ values of juices.

\begin{tabular}{lcc}
\hline Juices & $\mathrm{pH}$ range & Mean \\
\hline Orange & $4.19-4.50$ & 4.34 \\
Sweet lime & $4.70-5.47$ & 5.08 \\
Carrot & $5.76-6.03$ & 5.89 \\
\hline
\end{tabular}

were performed for the identification of bacteria such as catalase test, oxidase test, starch hydrolysis test, sugar fermentation test, IMViC test, and methods described in "Bergey's Manual of Systematic Bacteriology" [14]. Further identification of bacteria was performed on the basis of methods described in "Compendium of methods for the microbiological examination of foods" $[15,16]$.

2.5. Identification of Yeasts. The methods adopted for identification of yeasts include morphological characteristics, fermentation of sugars, germ tube test and cycloheximide resistance test, and methods described in "Fungi and Food Spoilage" $[17,18]$.

2.6. Identification of Moulds. Moulds were identified on the basis of morphological and cultural characteristics such as colour of the colony, surface, appearance, presence, and absence of cross walls, and asexual and sexual reproductive structures. Further identification of moulds was carried out according to the methods described in "Fungi and Food Spoilage." Moulds were cultured on Czapek yeast extract agar ( $\mathrm{pH}$ 6.7), Malt extract agar ( $\mathrm{pH}$ 5.6), and Glycerol nitrate agar $(\mathrm{pH} 7.0)$ at $25^{\circ} \mathrm{C}$.

\section{Results and Discussion}

In the present study, 30 samples of freshly prepared juices (10 samples each of orange, sweet orange, and carrot) were examined for microbiological analysis. The $\mathrm{pH}$ range of juices is shown in Table 1. Factors which determine the colonization of juices by microorganisms include $\mathrm{pH}$, redox potential, water activity, nutrients, structures, antimicrobial agents, temperature, relative humidity, and atmosphere [1]. In the present study the frequencies of occurrence of moulds and yeasts were more as compared to bacterial genera which is attributed to low $\mathrm{pH}$ values and high sugar content [19].

A total of 34 bacterial, 12 yeast, and 25 mould isolates were isolated from juices classified by grouping them into 9 bacterial species, 5 yeast species, and 11 mould species on the basis of phenotypic characteristics. Morphological and biochemical properties of bacteria were explained in Tables 2 and 3. Details of morphology and physiology of yeasts were described in Tables 4 and 5. Colonial and microscopic characteristics of various moulds were summarized in Tables 6 and 7.

Yeasts and moulds are capable of growth at $\mathrm{pH}$ values of 1.5 and at water activity values below 0.89 . The minimum $\mathrm{pH}$ values allowing the growth of lactic acid bacteria $(\mathrm{pH} 2.9-$ 3.5 ), acetic acid bacteria ( $\mathrm{pH} 3.0-4.5)$, and enteric bacteria (pH 3.6-4.5) are higher than those for growth of yeasts and moulds [6]. 
TABLE 2: Morphological characteristics of bacterial isolates of juices.

\begin{tabular}{|c|c|c|c|c|c|c|c|}
\hline $\begin{array}{l}\text { Bacterial } \\
\text { isolates }\end{array}$ & $\begin{array}{l}\text { Colour on nutrient } \\
\text { agar }\end{array}$ & Configuration & Margin & Elevation & $\begin{array}{c}\text { Gram } \\
\text { reaction }\end{array}$ & Shape of isolate & $\begin{array}{c}\text { Endospore } \\
\text { staining }\end{array}$ \\
\hline Bacillus subtilis & White & Circular lobate & Irregular & Flat & Positive & Rods in chains & Central spore \\
\hline B. cereus & Off-white & Circular & Entire & Convex & Positive & Rods in chains & Central spore \\
\hline Escherichia coli & Mucoid & Circular & Entire & Slightly raised & Negative & Rods & - \\
\hline Serratia & Mucoid & Circular & Entire & Umbonate & Negative & Rods & - \\
\hline Leuconostoc & Light yellow & Circular & Entire & Convex & Positive & Cocci & - \\
\hline Micrococcus & Bright Yellow & Circular & Entire & Convex & Positive & Cocci shape in tetrad & - \\
\hline $\begin{array}{l}\text { Staphylococcus } \\
\text { aureus }\end{array}$ & Golden yellow colour & $\begin{array}{c}\text { Circular pin } \\
\text { head colonies }\end{array}$ & Entire & Convex & Positive & $\begin{array}{c}\text { Cocci in grapes like } \\
\text { bunches }\end{array}$ & - \\
\hline Lactobacillus & White & Circular & Entire & Raised & Positive & Rods & - \\
\hline Acetobacter & Pale & Circular & Entire & Flat & Negative & Rods & - \\
\hline
\end{tabular}

-: absent.

TABLE 3: Biochemical characteristics of bacterial isolates of juices.

\begin{tabular}{|c|c|c|c|c|c|c|c|c|c|c|c|}
\hline \multirow{2}{*}{$\begin{array}{l}\text { Bacterial } \\
\text { isolates }\end{array}$} & \multirow[b]{2}{*}{ Catalase } & \multirow{2}{*}{ Oxidase } & \multirow{2}{*}{$\begin{array}{c}\text { Starch } \\
\text { hydrolysis }\end{array}$} & \multicolumn{4}{|c|}{ IMViC test } & \multicolumn{4}{|c|}{ Sugar fermentation } \\
\hline & & & & Indole & $\begin{array}{l}\text { Methyl } \\
\text { red }\end{array}$ & $\begin{array}{l}\text { Voges- } \\
\text { Proskauer }\end{array}$ & Citrate & Glucose & Lactose & Mannitol & Sucrose \\
\hline Bacillus subtilis & + & - & + & - & - & + & + & $\mathrm{A}$ & - & $\mathrm{A}$ & $\mathrm{A}$ \\
\hline B. cereus & + & - & + & - & - & + & + & A & - & A & - \\
\hline Escherichia coli & + & - & - & + & + & - & - & $A+G$ & $A+G$ & - & - \\
\hline Serratia & + & - & - & - & - & - & + & A & - & + & - \\
\hline Leuconostoc & - & - & - & - & - & + & + & $\mathrm{A}$ & - & A & - \\
\hline Micrococcus & + & + & - & + & + & - & - & $\mathrm{A}$ & $\mathrm{A}$ & - & - \\
\hline $\begin{array}{l}\text { Staphylococcus } \\
\text { aureus }\end{array}$ & + & - & - & + & + & - & - & A & A & A & A \\
\hline Lactobacillus & - & - & - & - & - & - & - & $A+G$ & $\mathrm{~A}$ & - & - \\
\hline Acetobacter & - & - & - & - & - & + & + & A & - & - & - \\
\hline
\end{tabular}

+: positive; -: negative; A: acid; A + G: acid + gas.

TABLE 4: Morphological details of yeast isolates of juices.

\begin{tabular}{lcccr}
\hline Yeast isolates & Colour on PDA & Configuration & Margin & Microscopic features \\
\hline Pichia & Off-white & Hemispherical & Irregular & Ellipsoidal to cylindrical; reproducing by irregular budding \\
$\begin{array}{l}\text { Saccharomyces } \\
\text { Candida krusei }\end{array}$ & Off-white & Circular & Irregular & Spherical to subspheroidal; reproducing by irregular budding \\
$\begin{array}{l}\text { Rhodotorula } \\
\text { Candida }\end{array}$ & Phite & Circular & Irregular & Ellipsoidal to long cylindrical; reproducing by irregular budding \\
parapsilosis & White to cream & Circular or spreading & Regular & Ellipsoidal shape; reproducing by irregular budding \\
\hline
\end{tabular}

TABle 5: Physiological tests for yeasts isolates of juices.

\begin{tabular}{|c|c|c|c|c|c|c|}
\hline \multirow{2}{*}{ Yeast isolate } & \multirow{2}{*}{ Germ tube test } & \multirow{2}{*}{ Cycloheximide resistance } & \multicolumn{4}{|c|}{ Sugar fermentation* } \\
\hline & & & Glucose & Sucrose & Lactose & Maltose \\
\hline Pichia & - & + & + & + & - & - \\
\hline Saccharomyces & - & - & + & + & - & - \\
\hline Candida krusei & - & - & + & - & - & - \\
\hline Rhodotorula & - & - & - & - & - & - \\
\hline Candida parapsilosis & - & - & + & - & - & - \\
\hline
\end{tabular}

+: positive; -: negative; ${ }^{*}$ fermentation means production of gas independent of $\mathrm{pH}$ changes. 
TABLE 6: Morphological details of mould isolates of juices.

\begin{tabular}{|c|c|c|c|}
\hline Mould isolate & $\begin{array}{l}\text { Colony colour } \\
\text { on PDA on } \\
\text { front side }\end{array}$ & $\begin{array}{l}\text { Colony colour } \\
\text { on PDA on } \\
\text { reverse side }\end{array}$ & Microscopic features \\
\hline Aspergillus flavus & Yellow green & Colourless & $\begin{array}{l}\text { Conidiophores arise separately from foot cell, phialides uniseriate and } \\
\text { sometimes biseriate; conidia globose to subglobose }\end{array}$ \\
\hline A. terreus & Brown & Colorless & $\begin{array}{l}\text { Conidiophore borne from surface hyphae, stripes long, and smooth walled; } \\
\text { vesicles with densely packed, short, narrow metulae and phialides; conidia } \\
\text { unicellular, spherical, and very small }\end{array}$ \\
\hline A. niger & Black & Creamy & $\begin{array}{l}\text { Hyphae septate and hyaline, smooth walled conidiophores arising from foot } \\
\text { cell; vesicles globose, whole vesicle fertile bearing two series of sterigmata; } \\
\text { catenate conidia arranged in basipetal manner, unicellular, and globose }\end{array}$ \\
\hline Penicillium islandicum & Ivy green & Creamy & $\begin{array}{l}\text { Short conidiophores bearing a compact verticil of metulae, phialides closely } \\
\text { packed in clusters bearing catenate conidia arranged in basipetal manner, } \\
\text { conidia elliptical, smooth, and hyaline }\end{array}$ \\
\hline P. digitatum & Green & Colourless & $\begin{array}{l}\text { Conidiophores borne from surface and aerial hyphae with thin smooth walls; } \\
\text { bearing terminal penicilli; terverticillate but frequently biverticillate or irregular }\end{array}$ \\
\hline Alternaria & Black & Colourless & $\begin{array}{l}\text { Small to large sized conidia with beak; arising in chains in acropetal manner } \\
\text { with both transverse and longitudinal septa }\end{array}$ \\
\hline Cladosporium & Black & Colourless & $\begin{array}{l}\text { Conidiophore tall, dark upright, and branched variously near the apex, conidia } \\
\text { 1-2-celled ovoid to cylindrical shape }\end{array}$ \\
\hline Colletotrichum & $\begin{array}{l}\text { Cottony white } \\
\text { to pale gray } \\
\text { mycelium } \\
\end{array}$ & Colourless & $\begin{array}{l}\text { Acervuli disc shaped, typically with dark spines or setae at the edge of } \\
\text { conidiophores; conidiophores simple, elongate conidia single celled, hyaline or } \\
\text { brightly coloured, cylindrical or pointed, straight or curved }\end{array}$ \\
\hline Curvularia & $\begin{array}{l}\text { Green to } \\
\text { black }\end{array}$ & Black & $\begin{array}{l}\text { Simple conidiophores bearing spores apically; Conidia dark, end cells, } \\
\text { 3-5-celled; more or less fusiform, typically bent }\end{array}$ \\
\hline Fusarium & Wooly white & Colourless & $\begin{array}{l}\text { Conidiophores slender and simple, short or branched irregularly or bearing a } \\
\text { whorl of phialides; conidia hyaline, variable, principally of two kinds, } \\
\text { macroconidia several celled slightly curved or bent at the point ends, } \\
\text { microconidia 1-celled, ovoid or oblong, borne singly or in chains }\end{array}$ \\
\hline Geotrichum & White & Colourless & Conidia borne solely by the breakup of hyphae to form arthroconidia \\
\hline
\end{tabular}

TABLE 7: Colonial characteristics of different moulds' isolates of juices on CYA, MEA, and G25N media.

\begin{tabular}{|c|c|c|c|c|c|c|}
\hline \multirow{2}{*}{ Mould isolate } & \multicolumn{2}{|c|}{ Colony colour on CYA } & \multicolumn{2}{|c|}{ Colony colour on MEA } & \multicolumn{2}{|c|}{ Colony colour on G25N } \\
\hline & Front side & Reverse side & Front side & Reverse side & Front side & Reverse side \\
\hline $\begin{array}{l}\text { Aspergillus } \\
\text { flavus }\end{array}$ & Yellow green & Colourless & Yellow green & Colourless & Yellow green & Colourless \\
\hline A. terreus & Brown & Dull brown & Brown & Dull brown & Brown & Dull brown \\
\hline A. niger & Black & $\begin{array}{c}\text { Pale to bright } \\
\text { yellow }\end{array}$ & Black & $\begin{array}{c}\text { Pale to bright } \\
\text { yellow }\end{array}$ & Black & $\begin{array}{c}\text { Pale to bright } \\
\text { yellow }\end{array}$ \\
\hline $\begin{array}{l}\text { Penicillium } \\
\text { islandicum }\end{array}$ & Greyish green & $\begin{array}{l}\text { Orange to } \\
\text { rust brown } \\
\text { central area }\end{array}$ & Greyish green & $\begin{array}{l}\text { Orange to } \\
\text { rust brown } \\
\text { central area }\end{array}$ & Greyish green & $\begin{array}{l}\text { Orange to } \\
\text { rust brown } \\
\text { central area }\end{array}$ \\
\hline P. digitatum & $\begin{array}{c}\text { Greyish } \\
\text { green to olive }\end{array}$ & Pale or brown & $\begin{array}{c}\text { Dull yellow } \\
\text { green }\end{array}$ & Pale or brown & Green olive & Pale \\
\hline Alternaria & Grey to black & Black & Grey to black & Black & Grey to black & Black \\
\hline Cladosporium & $\begin{array}{c}\text { Olive to dark } \\
\text { olive }\end{array}$ & Grey & Olive & Grey & Olive & Black \\
\hline Colletotrichum & Grey & Pale grey & Grey & Pale grey & Black & Grey \\
\hline Curvularia & $\begin{array}{l}\text { Off-white to } \\
\text { grey }\end{array}$ & Grey & $\begin{array}{l}\text { Off-white to } \\
\text { grey }\end{array}$ & Grey & Grey to black & Grey \\
\hline Fusarium & $\begin{array}{c}\text { White to } \\
\text { grayish rose }\end{array}$ & Pale & White & Pale & White & Pale \\
\hline Geotrichum & White & Pale & White & Pale & $\mathrm{No}$ & vth \\
\hline
\end{tabular}


TAble 8: Percentage abundance of bacterial isolates in juice samples.

\begin{tabular}{|c|c|c|c|c|c|}
\hline Bacterial isolates & $\begin{array}{l}\text { Orange juice } \\
\quad(n=10)\end{array}$ & $\begin{array}{l}\text { Sweet orange juice } \\
\qquad(n=10)\end{array}$ & $\begin{array}{c}\text { Carrot juice } \\
\quad(n=10)\end{array}$ & Total number of samples & Percentage frequency \\
\hline Bacillus subtilis & 5 & 3 & 4 & 12 & $40 \%$ \\
\hline B. cereus & 8 & 4 & 5 & 17 & $56.7 \%$ \\
\hline Escherichia coli & 2 & 3 & 1 & 6 & $20.0 \%$ \\
\hline Serratia & 5 & 5 & 4 & 14 & $46.7 \%$ \\
\hline Leuconostoc & 4 & 5 & - & 9 & $30.0 \%$ \\
\hline Micrococcus & - & 3 & - & 3 & $10.0 \%$ \\
\hline Staphylococcus aureus & 2 & 1 & 2 & 5 & $16.7 \%$ \\
\hline Lactobacillus & 2 & 3 & 2 & 7 & $23.3 \%$ \\
\hline Acetobacter & 3 & 5 & - & 8 & $26.7 \%$ \\
\hline
\end{tabular}

-: absent.

TABLE 9: Percentage abundance of yeast isolates in juice samples.

\begin{tabular}{lccccc}
\hline Yeast isolates & $\begin{array}{c}\text { Orange juice } \\
(n=10)\end{array}$ & $\begin{array}{c}\text { Sweet orange juice } \\
(n=10)\end{array}$ & $\begin{array}{c}\text { Carrot juice } \\
(n=10)\end{array}$ & Total number of samples & Percentage frequency \\
\hline Pichia & 8 & 7 & 4 & 19 & $63.3 \%$ \\
Saccharomyces & 6 & 8 & 4 & 17 & $56.67 \%$ \\
Candida krusei & 3 & 8 & - & 11 & $36.7 \%$ \\
Rhodotorula & 9 & 6 & - & 24 & $80 \%$ \\
Candida parapsilosis & 8 & - & & 8 & $26.7 \%$ \\
\hline
\end{tabular}

-: absent.

TABLE 10: Percentage abundance of mould isolates in juice samples.

\begin{tabular}{|c|c|c|c|c|c|}
\hline Mould isolates & $\begin{array}{l}\text { Orange juice } \\
\quad(n=10)\end{array}$ & $\begin{array}{l}\text { Sweet lime juice } \\
\qquad(n=10)\end{array}$ & $\begin{array}{l}\text { Carrot juice } \\
\quad(n=10)\end{array}$ & Total number of samples & $\begin{array}{c}\text { Percentage frequency = } \\
\text { occurrence in observed } \\
\text { samples/total no of samples }\end{array}$ \\
\hline Aspergillus flavus & 9 & 9 & 7 & 25 & $83.3 \%$ \\
\hline A. terreus & 5 & 7 & 4 & 16 & $53.3 \%$ \\
\hline A. niger & 3 & 2 & 1 & 6 & $20 \%$ \\
\hline Penicillium islandicum & 9 & 7 & 7 & 23 & $76.7 \%$ \\
\hline P. digitatum & 7 & 5 & - & 12 & $40 \%$ \\
\hline Alternaria & 6 & 5 & 3 & 14 & $46.7 \%$ \\
\hline Cladosporium & 3 & 4 & 2 & 9 & $30 \%$ \\
\hline Colletotrichum & 5 & 3 & - & 8 & $26.7 \%$ \\
\hline Curvularia & 3 & 2 & - & 5 & $16.7 \%$ \\
\hline Fusarium & 4 & 6 & 3 & 13 & $43.3 \%$ \\
\hline Geotrichum & 4 & - & 3 & 7 & $23.3 \%$ \\
\hline
\end{tabular}

-: absent.

The frequency of occurrence of bacteria, yeasts, and moulds are summarized in Tables 8,9 , and 10, respectively. The occurrence of bacterial genera ranged from $10 \%$ to $56 \%$ (Table 8). Bacillus cereus and Serratia sp. were detected in a greater number of samples. Bacillus cereus was also observed in $64.91 \%$ of samples of unpasteurized street vended fruit juices [20]. Leuconostoc and Lactobacillus were also reported as important group of spoilage microorganisms in acidic products [21]. The presence of lactic acid bacteria more frequently occurs in unpasteurized juices [22]. These microorganisms produce acetic and formic acids along with ethanol and carbon dioxide which can alter the flavor of juice [23]. Leuconostoc, Lactobacillus, and Acetobacter were detected in tested juice samples (Table 8 ).

The presence of E. coli, Salmonella, and S. aureus in fruit juices is primarily concern because these pathogens were implicated in a number of outbreaks associated with fruit juices [1]. In our study, the presence of E. coli and S. aureus was detected in a smaller number of samples. The survival of pathogens in acidic environment of juices is attributed to their ability to regulate their internal $\mathrm{pH}$ and maintained at neutral $\mathrm{pH}$ by combination of passive and active homeostasis 
mechanisms [24]. The acid survival mechanisms of enteric bacteria are due to induction of enzymes that are involved in raising the internal $\mathrm{pH}$ and activation of enzymes devoted to the protection and repair of proteins and DNA [25].

Yeasts genera responsible for spoilage of fruit juices include Candida, Pichia, Rhodotorula, Torulopsis, Saccharomyces, Zygosaccharomyces, Hansenula, and Trichosporon [26]. In our study, the dominant yeasts isolated from juices were Rhodotorula, Pichia, and Saccharomyces (Table 9). Rhodotorula was found in maximum number of juice samples tested followed by Pichia and Saccharomyces. Candida parapsilosis and C. krusei were only detected in orange and sweet orange juices, not detected in carrot juice. Ghenghesh et al. [9] also reported the presence of Candida sp. in 58\% of orange juice samples. Rhodotorula, Pichia, Candida, and Saccharomyces have also been reported as spoilage causing organisms in pasteurized fruit juices $[4,27]$. Yeast spoilage in fruit juices is characterized by formation of $\mathrm{CO}_{2}$ and alcohol. Yeasts may also produce turbidity, flocculation, pellicles, and clumping. Yeasts also produced pectin esterases which degrade pectin causing spoilage; organic acids and acetaldehyde, which contribute to a "fermented flavor," may also be formed $[5,6]$.

The dominant moulds recorded in fruit juices belong to Penicillium sp., Cladosporium sp., Aspergillus niger, A. fumigatus, Botrytis sp., and Aureobasidium pullulans. They produce mycelial mats and musty, stale off-flavours in juices [6]. Rhizopus and Mucor are also associated with spoilage of fresh fruits and vegetables [28]. In the present study, the most frequently encountered moulds were Aspergillus flavus, A. terreus, and Penicillium islandicum (Table 5). P. digitatum, Colletotrichum, and Curvularia were isolated from orange and sweet orange juices. Geotrichum was detected in orange and carrot juice. Spoilage by moulds in fruit juices is characterized by loss of juice cloud [6]. Among these, some moulds produce mycotoxins which are of great threat to human health. Major mycotoxins associated with fruit juices are byssochlamic acid (Byssochlamys fulva, B. nivea), patulin (B. fulva, B. nivea, and P. expansum), ochratoxin (Aspergillus carbonarius), and citrinin (Penicillium expansum, P. citrinum) $[29,30]$.

\section{Conclusion}

Juices squeezed from fresh fruits and vegetables contain microorganisms which are potentially hazardous to public health. Juices were spoiled with high level of moulds and yeasts which is attributable to low $\mathrm{pH}$ of juices. The presence of pathogenic microorganisms in juices is clearly indication of food borne outbreaks. The selling and consumption of juices are never stopped on nutritional grounds as well as livelihood of street vendors. It is alarming situation for suitable agency to take some necessary action, make guidelines to prevent potential food poisoning from juices that contain pathogenic bacteria, and find natural antimicrobials from plants that control spoilage and pathogenic microorganisms in juices.

\section{Conflict of Interests}

The authors declare that there is no conflict of interests regarding the publication of this paper.

\section{Acknowledgment}

The authors are thankful to Kurukshetra University, Kurukshetra, for the financial assistance.

\section{References}

[1] R. M. Raybaudi-Massilia, J. Mosqueda-Melgar, R. Soliva-Fortuny, and O. Martín-Belloso, "Control of pathogenic and spoilage microorganisms in fresh-cut fruits and fruit juices by traditional and alternative natural antimicrobials," Comprehensive Reviews in Food Science and Food Safety, vol. 8, no. 3, pp. 157180, 2009.

[2] R. M. U. S. K. Rathnayaka, "Antibacterial effect of malic acid against Listeria monocytogenes, Salmonella enteritidis and Escherichia coli in Mango, Pineapple and Papaya juices," American Journal of Food Technology, vol. 8, no. 1, pp. 74-82, 2013.

[3] International Federation of Fruit Juice Producers Union, Fruit Juice Nutrition and Health-Scientific Review, 2011.

[4] V. H. Tournas, J. Heeres, and L. Burgess, "Moulds and yeasts in fruit salads and fruit juices," Food Microbiology, vol. 23, no. 7, pp. 684-688, 2006.

[5] ICMSF, "Soft drinks, fruit juices, concentrates and food preserves," in Microorganisms in Foods 6: Microbial Ecology of Food Commodity, Kluwer Academic, 2005.

[6] K. A. Lawlor, J. D. Schuman, P. G. Simpson, and P. J. Taormina, "Microbiological spoilage of beverages," in Compendium of the Microbiological Spoilage of Foods and Beverages, W. H. Sperber and M. P. Doyle, Eds., Food Microbiology and Food Safety, pp. 245-284, Springer, New York, NY, USA, 2009.

[7] I. Sospedra, J. Rubert, J. M. Soriano, and J. Mañes, "Incidence of microorganisms from fresh orange juice processed by squeezing machines," Food Control, vol. 23, no. 1, pp. 282-285, 2012.

[8] A. Bevilacqua, M. R. Corbo, D. Campaniello et al., "Shelf life prolongation of fruit juices through essential oils and homogenization: a review," in Science against Microbial Pathogens: Communicating Current Research and Technological Advances, pp. 1156-1166, 2011.

[9] K. S. Ghenghesh, K. Belhaj, W. B. El-Amin, S. E. El-Nefathi, and A. Zalmum, "Microbiological quality of fruit juices sold in Tripoli-Libya," Food Control, vol. 16, no. 10, pp. 855-858, 2005.

[10] A. Titarmare, P. Dabholkar, and S. Godbole, "Bacteriological analysis of street vended fresh fruit and vegetable juices in Nagpur city, India," Internet Journal of Food Safety, vol. 11, pp. 1-3, 2009.

[11] J. E. Lewis, P. Thompson, B. Rao, C. Kalavati, and B. Rajanna, "Human Bacteria in street vended fruit juices: a case study of Vishakhapatnam city, India," Internet Journal of Food Safety, vol. 8, pp. 35-38, 2006.

[12] D. P. Mahale, R. G. Khade, and K. V. Vaidya, "Microbiological analysis of street vended fruit juices from Mumbai city, India," Internet Journal of Food Safety, vol. 10, pp. 31-34, 2008.

[13] D. H. Tambeker, V. J. Jaiswal, D. V. Dhanorker, P. B. Gulhane, and M. N. Dudhane, "Microbial quality and safety of street vended fruit juices: a case study of Amravati city," Internet Journal of Food Safety, vol. 10, pp. 72-76, 2009.

[14] W. B. Whitman, M. Goodfellow, P. Kämpfer et al., Bergey's Manual of Systematic Bacteriology, vol. 5, 2012.

[15] American Public Health Association, Compendium of Methods for the Microbiological Examination of Foods, APHA, Washington, DC, USA, 4th edition, 2001. 
[16] A. Vantarakis, M. Affifi, P. Kokkinos, M. Tsibouxi, and M. Papapetropoulou, "Occurrence of microorganisms of public health and spoilage significance in fruit juices sold in retail markets in Greece," Anaerobe, vol. 17, no. 6, pp. 288-291, 2011.

[17] T. Chand-Goyal and R. A. Spotts, "Enumeration of bacterial and yeast colonists of apple fruits and identification of epiphytic yeasts on pear fruits in the Pacific Northwest United States," Microbiological Research, vol. 151, no. 4, pp. 427-432, 1996.

[18] I. J. Pitt and A. D. Hocking, Fungi and Food Spoilage, Springer, New York, NY, USA, 3rd edition, 2009.

[19] A. Rivas, D. Rodrigo, A. Martínez, G. V. Barbosa-Cánovas, and M. Rodrigo, "Effect of PEF and heat pasteurization on the physical-chemical characteristics of blended orange and carrot juice," LWT-Food Science and Technology, vol. 39, no. 10, pp. 1163-1170, 2006.

[20] M. S. U. Ahmed, T. Nasreen, B. Feroza, and S. Parveeen, "Microbiological quality of local market vended freshly squeezed fruit juices in Dhaka city, Bangladesh," Bangladesh Journal of Scientific and Industrial Research, vol. 44, no. 4, pp. 421-424, 2009.

[21] S. E. Keller and A. J. Miller, "Microbial safety of fresh citrus and apple juices," in Microbiology of Fruits and Vegetables, G. M. Sapers, J. R. Gorny, and A. E. Yousef, Eds., chapter 9, Taylor \& Francis, Boca Raton, Fla, USA, 2006.

[22] J. C. Oliveira, P. Setti-Perdigão, K. A. G. Siqueira, A. C. Santos, and M. A. L. Miguel, "Microbiological characteristics of orange juices," Ciencia e Tecnologia de Alimentos, vol. 26, no. 2, pp. 241245, 2006.

[23] S. Jay and J. Anderson, "Fruit juice and related products," in Spoilage of Processed Foods: Causes and Diagnosis, C. J. Moir, C. Andrew-Kabilafkas, G. Arnold, B. M. Cox, A. D. Hocking, and I. Jenson, Eds., pp. 187-198, Southwood Press, Sydney, Australia, 2001.

[24] N. Beales, "Adaptation of microorganisms to cold temperatures weak acid preservatives low $\mathrm{pH}$ and osmotic stress: a review," Comprehensive Reviews in Food Science and Food Safety, vol. 3, no. 1, pp. 1-20, 2004.

[25] S. Bearson, B. Bearson, and J. W. Foster, "Acid stress responses in enterobacteria," FEMS Microbiology Letters, vol. 147, no. 2, pp. 173-180, 1997.

[26] A. Renard, P. Gómez di Marco, M. Egea-Cortines, and J. Weiss, "Application of whole genome amplification and quantitative PCR for detection and quantification of spoilage yeasts in orange juice," International Journal of Food Microbiology, vol. 126, no. 1-2, pp. 195-201, 2008.

[27] S. Mendoza, L. Montemayor, L. A. Boscan, and J. A. Barreiro, "Microflora in pasteurized fruit juices in Venezuela," Archivos Latinoamericanos de Nutrición, vol. 32, no. 3, pp. 617-629, 1982.

[28] M. O. Moss, "Fungi, quality and safety issues in fresh fruits and vegetables," Journal of Applied Microbiology, vol. 104, no. 5, pp. 1239-1243, 2008.

[29] P. Wareing and R. R. Davenport, "Microbiology of soft drinks and fruit juices," in Chemistry and Technology of Soft Drinks and Fruit Juices, P. R. Ashurst, Ed., Blackwell Publishing, London, UK, 2005.

[30] N. Delage, A. Harlingue, B. C. Ceccaldi, and G. Bompeix, "Mycotoxins in fruit juices and wine," Food Control, vol. 14, pp. 2252-2257, 2003. 

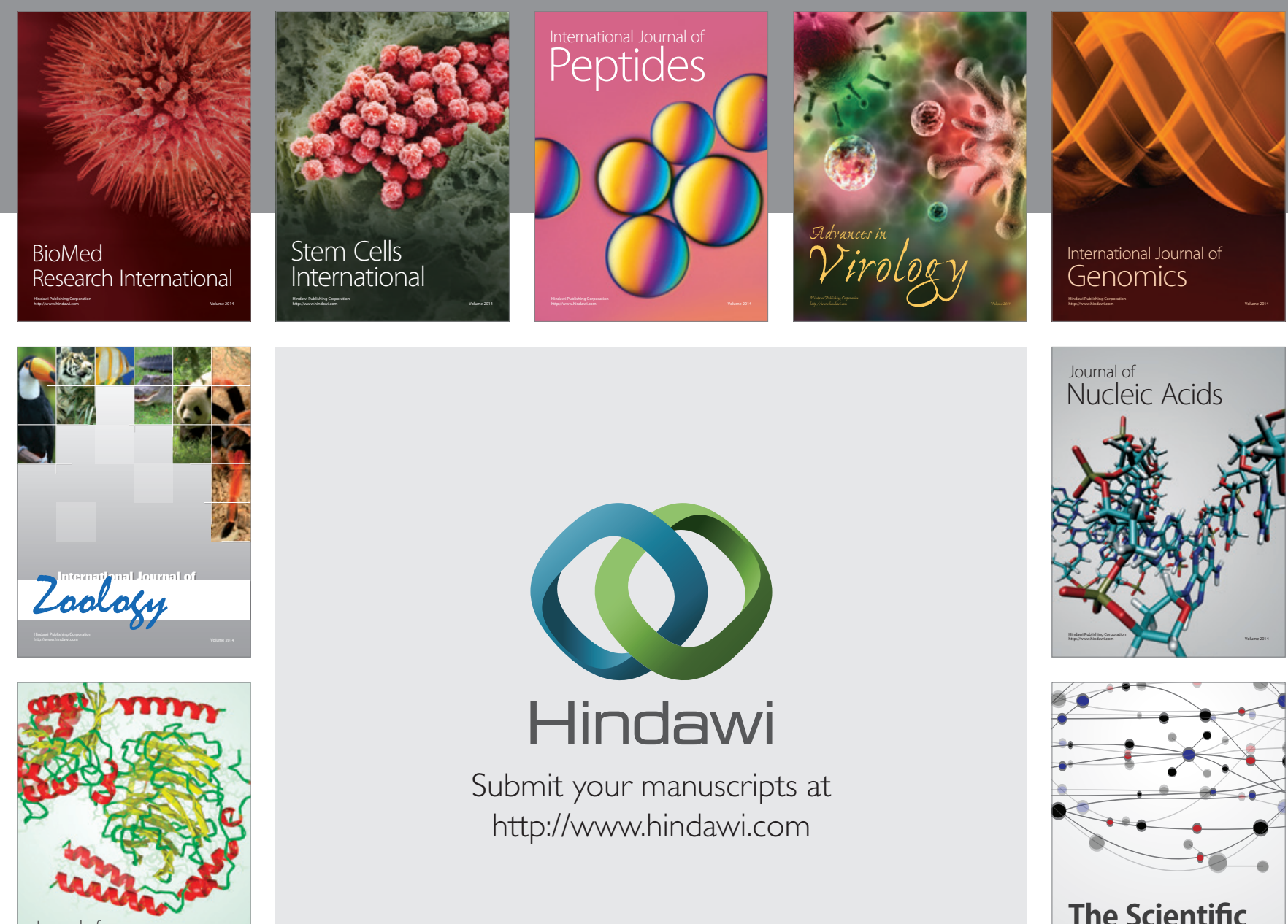

Submit your manuscripts at

http://www.hindawi.com

Journal of
Signal Transduction
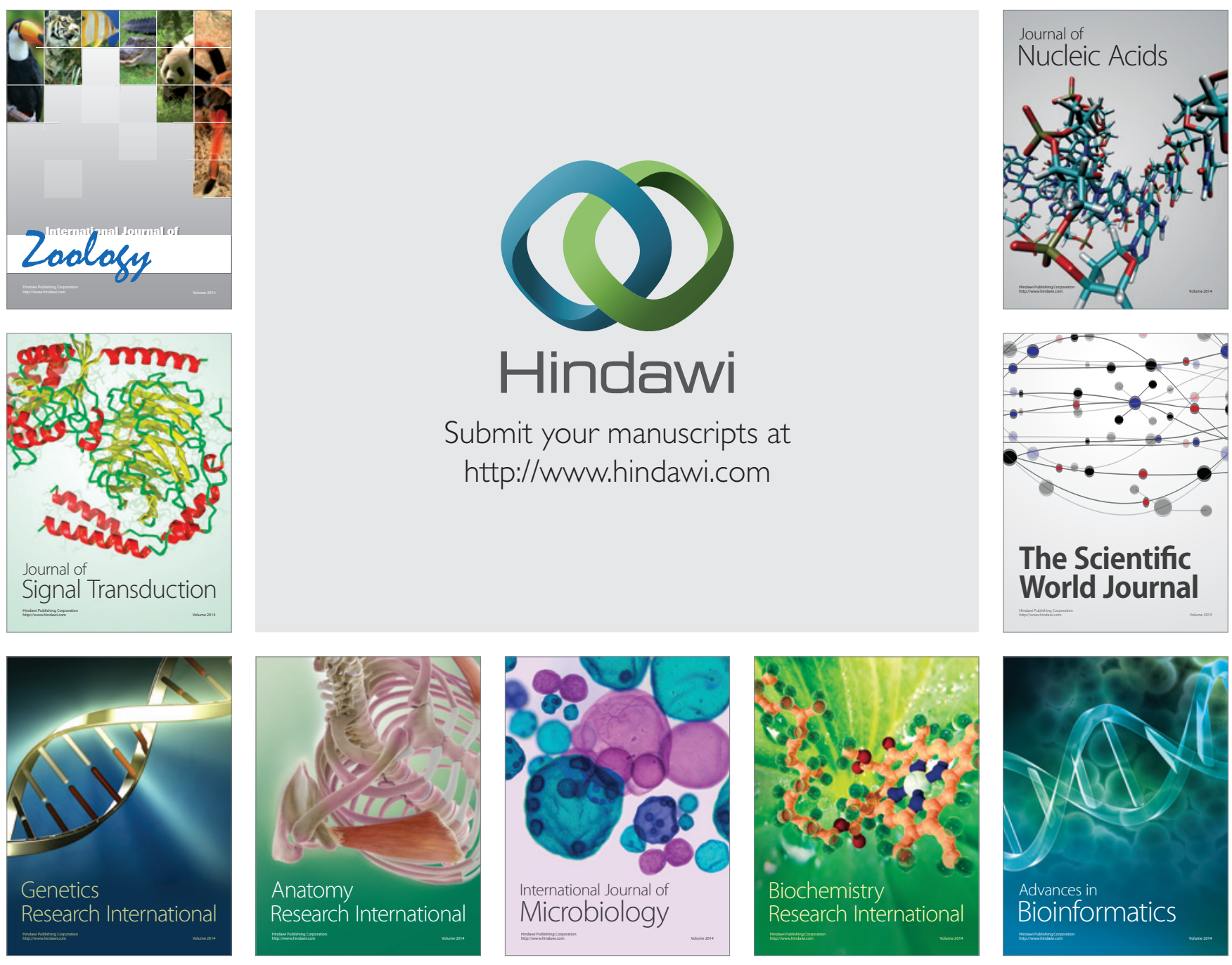

The Scientific World Journal
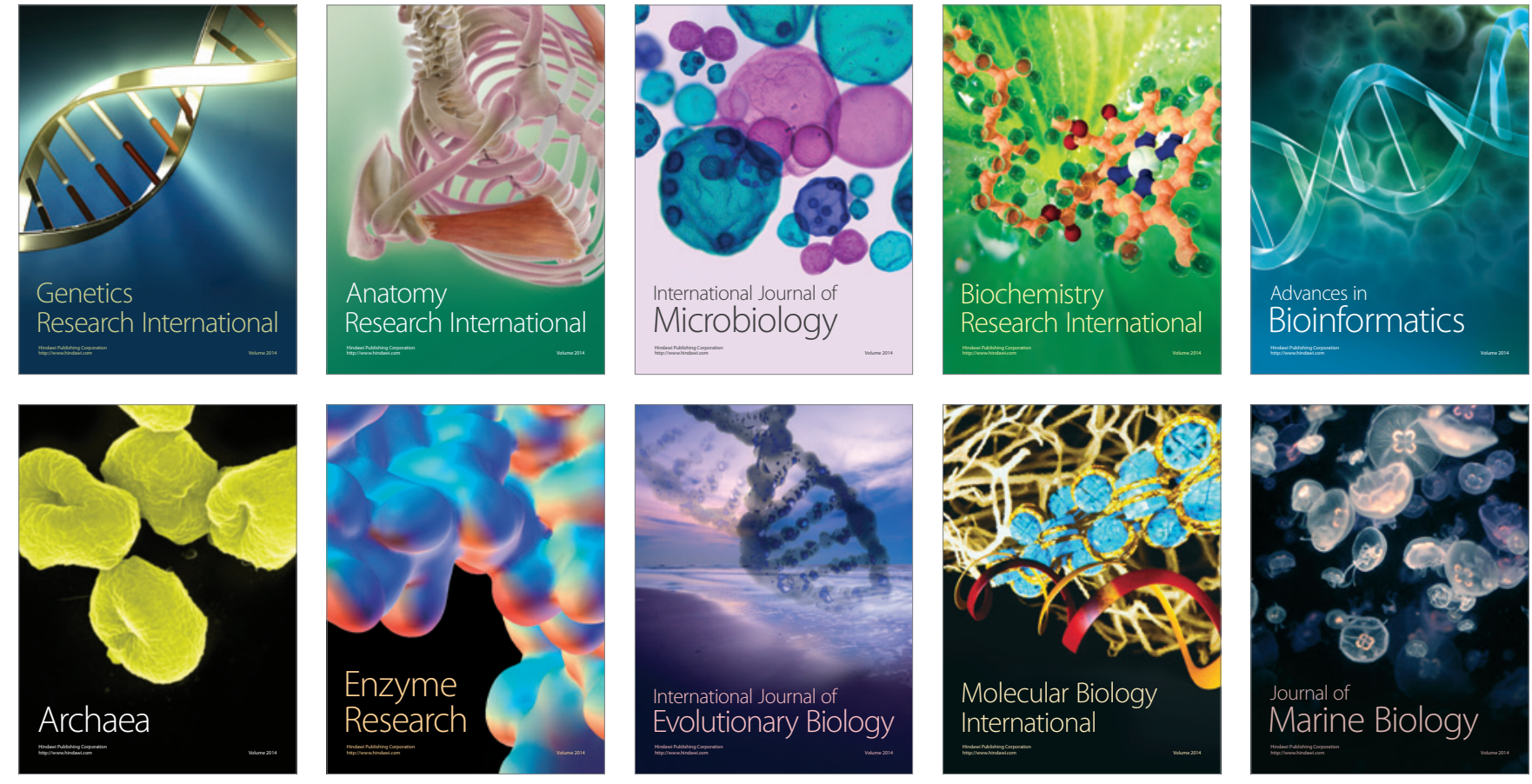